\title{
GENETIC VARIABILITY FOR TUBER YIELD, QUALITY, AND VIRUS DISEASE COMPLEXTRAITS IN UGANDA SWEETPOTATO GERMPLASM
}

\author{
E. GASURA, A.B. MASHINGAIDZE ${ }^{1}$ and S.B. MUKASA \\ Department of Crop Science, Makerere University, P. O. Box 7062 Kampala, Uganda \\ ${ }^{1}$ Department of Crop Science, University of Zimbabwe, P. O. Box MP167, Mt Pleasant, Harare, Zimbabwe
}

(Received 12 January, 2007; accepted 9 May, 2008)

\begin{abstract}
Sweetpotato (Ipomoea batatas) is an important root crop in Uganda, where yield potential and quality attributes have not been fully exploited due to limited breeding efforts and poor knowledge on the inheritance of some of its agronomic traits. A study was carried out at Makerere University to phenotypically characterise selected sweetpotato cultivars with special reference to sweet potato virus disease (SPVD) resistance, growth habit, flowering and seed set ability, tuber yield and shape, tuber skin and flesh colour, dry matter, starch, sugar and $\beta$ carotene content. Twenty cultivars were selected for use in the assessment of their breeding potential and for improvement of yield and quality attributes. Cultivar Munyeera displayed the highest level of SPVD resistance followed by New Kawogo and Polyster as exhibited by relative area under disease progress curves following natural field infection and graft inoculation with SPVD causing viruses, Sweet potato chlorotic stunt virus and Sweet potato feathery mottle virus. Flowering ability was low in some cultivars and a few did not flower at all. Some cultivars e.g. Munyeera, New Kawogo, Silk and Sowola which showed high flowering ability failed to fertilise and set seed when crossed to specific cultivars. Preliminary genetic analysis for yield and quality following crossing elite 7 female and 6 male cultivars in a North Carolina 2 mating design showed wide genetic variability in the $\mathrm{F}_{1} \mathrm{~s}$ for the important traits, and heterosis was observed for some traits such as tuber size and number of tubers per plant. Up to five genes may be involved in $\beta$-carotene synthesis and probably in combination with other genes in different genetic backgrounds that can modify flesh colour from white to purple. The results demonstrate the possibility to improve sweetpotato for yield and quality using the available germplasm.
\end{abstract}

Key Words: $\beta$-carotene, dry matter content, Ipomoea batatas, SPCSV, SPFMV and SPVD

\section{RÉSUMÉ}

La patate douce (Ipomoea batatas) est une plante à racine importante en Ouganda, où le rendement potentiel et les attributs qualitatifs n'ont pas encore été entièrement exploités suite aux efforts limités d'amélioration et faibles connaissances sur l'héritabilité de certains de ses traits agronomiques. Une étude a été effectuée à l'Université de Makerere pour une caractérisation phenotypique des cultivars de patate douce selectionnés avec une considération toute particulière à la résistance à la maladie de virus de patate douce (SPVD), le mode de croissance, l'aptitude de floraison et de fructification, le rendement et la forme de tubercule, la couleur de la peau et de la chair, la matière sèche, l'amidon, le sucre et la teneur en $\beta$-carotène. Vingt cultivars ont été selectionnés et utilisés pour l'évaluation du potentiel d'amélioration, d'accroissement du rendement et des attributs qualitatifs. Le cultivar Munyeera a montré le plus haut niveau de résistance au SPVD suivie de New Kawogo et Polyster comme exhibé par la surface sous les courbes de progression de la maladie selon l'infection naturelle du champ et l'inoculation de greffe avec SPVD causant les virus, le virus chlorotic de patate douce et le virus plumeux de marbrure de patate douce (Sweet potato chlorotic stunt virus et Sweet potato feathery mottle virus). L'aptitude de floraison était basse dans quelques cultivars et peu d'entre eux n'ont pas fleuri du tout. Quelques cultivars, par exemple Munyeera, New Kawogo, Silk et Sowola qui ont montré l'aptitude de floraison ont été incapables de feconder et de produire des semences lorsque croisés avec des cultivars spécifiques. L'analyse génétique préliminaire 
pour le rendement et la qualité suivant le croisement de 7 élites femelles avec 6 cultivars mâles dans un modèle de croisement North Carolina 2 a montré une large variabilité génétique dans les $F_{1} s$ pour les traits importants, et l'hétérosis a été observée pour certains traits tels que la grosseur de tubercules et le nombre de tubercules par plante. Jusqu'à cinq gènes seraient impliqués dans la synthese de $\beta$-carotene et probablement en combinaison avec d'autres gènes dans différents facteurs génétiques de base susceptibles de modifier la couleur de chair de blanc en pourpre. Les résultats démontrent la possibilité d'améliorer le rendement et la qualité de la patate douce en utilisant le germplasm disponible.

Mots Clés: $\beta$-carotène, teneur en matière sèche, Ipomoea batatas, SPCSV, SPFMV et SPVD

\section{INTRODUCTION}

Sweetpotato (Ipomoea batatas) is an important food crop in many areas of sub-Saharan Africa, where the crop is grown on about 2.1 million hectares (FAO, 2004), with an estimated production of 9.9 million tons (CIP, 1999). In Uganda, it ranks as the second most important food crop after cassava in the eastern region and second to banana (Musa sp.) in the central and western regions (Mukasa et al., 2003). Despite its great potential to alleviate widespread food insecurity, malnutrition and poverty, it has remained the untapped resource in many developing countries (Woolfe, 1992).

In Uganda, there are many challenges to sweetpotato production and utilisation, thus calling for breeding efforts. For example, the incidence of the devastating sweet potato virus disease (SPVD) (Gibson et al., 1998) is widespread in the major sweetpotato growing areas (Mukasa et al., 2003). Alternaria leaf and stem blight disease and weevil problems have been reported (Mwanga et al., 2002). The rising demand for food due to rapid population growth and urbanisation cannot be adequately sustained by the low yields normally found in the traditional cropping systems. The importance and nutritive value of sweetpotato as either food or feed has been well documented (Woolfe, 1992). Nevertheless, the current improved varieties have poor nutritional qualities in terms of vitamin A and protein content.

Sweetpotato quality attributes in East Africa were described by Rees et al. (2003) and the areas where breeding initiatives should be emphasized were highlighted. Rees et al. (2003) ranked viruses and weevils as most important, followed by yield, earliness in maturity, starch and dry matter content, sweetness (taste), fiber content, level of flesh oxidation, root shape, skin and lastly flesh colour. White flesh colour was ranked more acceptable than orange flesh colour (Rees et al., 2003); because generally the orange fleshed varieties have low dry matter content which makes them less acceptable by farmers and end users.

Sweetpotato is one of the most under exploited of the developing world's major crops (Rees et al., 2003), as evidenced by its breeding initiatives that are at relatively early stages compared to other crops. The need to identify local germplasm with desirable traits has long been recognised by breeders (Rees et al., 2003). Local germplasm is more desirable than exotic ones since in most cases such accessions are better adapted to the local agro-ecological environments. Many of the recently introduced clones have shown high yield potential but were very susceptible to the devastating SPVD (Mwanga et al., 2002). This underpins the need for local breeding programs that exploit the potential of local germplasm.

It has been long known that many sweetpotato traits are mainly quantitatively inherited (Jones, 1986). Genetic-statistical methodologies that assist in the selection of parents, based on their combining abilities and potential to produce promising segregating populations have been developed (Griffings, 1956). Hahn et al. (1981) estimated broad sense heritability of resistance to SPVD to be between 0.48-0.98 and later Mwanga et al. (2002) reported high broad-sense heritability (0.73-0.98) and medium narrow sense heritability (0.41-0.60) for resistance to SPVD. This suggests that rapid genetic gain in breeding for resistance to SPVD is possible. The heritability of tuber yield, tuber 
shape and tuber number were found to be low (Wilson et al., 1989). However, the heritability of growth habit, skin colour, $\beta$-carotene content, starch content and protein content were found to be moderate to high (Wilson et al., 1989). The evaluation and characterisation of populations with high frequency of favorable alleles for desirable traits can support breeding programs through selection and crossing of the parents which are more likely to have a positive effect on the desired traits. Such an evaluation allows breeders to concentrate efforts in those populations with higher potential of producing superior progenies.

To meet the quality needs there is a need to take into account the farmer and consumer preferences when developing and selecting sweetpotato varieties and in most cases this can be addressed through participatory variety selection. Fortunately, the attributes considered most important by farmers and consumers were already identified and ranked by Rees et al. (2003). Given the enormous genetic diversity of sweetpotato in Uganda (Mukasa et al., 2003), the possibility for sweetpotato improvement to accommodate specific uses is expected to be rapid (Rees et al., 2003). The aim of this study was to assess the breeding potential of sweetpotato genotypes in Uganda, which can further guide in selecting the parental genotypes that can be exploited in simultaneous combination of these traits in a common genetic background.

\section{MATERIALS AND METHODS}

Plant materials. Based on yield and quality attributes, 22 sweetpotato cultivars were used in this study. They composed of locally bred clones, introductions and landraces. These included sweetpotato cultivars Araka Red, Araka White, Beauregard, Bitambi, Buliribwamese, Busia, Bwanjule, Dimbuka, Enjumula, Kikuyu, Kisakyamaria, Kyebandula, Munyeera, Nashu, NASPOT 1, New Kawogo, Polyster, Silk, Sowola, Sudan, Tanzania and Tar. Due to lack of planting materials at the beginning of the experiments cultivars Busia and Dimbuka were only used in the field and agronomic experiments.
Phenotypic characterisation of selected sweetpotato cultivars. A total of 20 sweetpotato cultivars were planted in the field in a randomised complete block design (RCBD), replicated twice at Makerere University Agricultural Research Institute Kabanyolo (MUARIK). Two months after planting, the cultivars were phenotypically characterised basing on vine, leaf, floral and tuber traits using the CIP/IBPGR descriptors as described by Huaman (1991). For quantitative traits, a mean from five observations was obtained. The phenotypic data were coded into binary and used to calculate distance matrices as described by Nei and Li (1979). Using the TREECON software, a dendrogram was produced with the neighbor joining algorithm.

\section{Evaluating sweetpotato cultivar reaction to} natural infection with viruses in the field. Evaluation of cultivar reaction to natural infection with SPVD causing viruses in the field was done in a RCBD, with 2 replications. Each plot was planted with 3 rows of the healthy looking plants of a given test cultivar and two rows of SPVD diseased plants of cultivar Tanzania. The cultivars to be tested were planted in a plot in such a way that each healthy row was next to a row of diseased plants (spreader row). The incidence and severity of SPVD were evaluated every month for five months after planting. The severity was scored on a scale of 1-5 as described by Hahn (1979). The SPVD incidences were expressed as a percentage of diseased plants compared to the total number of plants present. Based on plot average in each block, the areas under disease progress curves (AUDPCs) for both severity scores and percent incidence were calculated according to Campbell and Madden (1990) as follows; AUDPC $=\sum_{1}^{n-1}\left(i_{1}+i_{2}\right) / 2\left(t_{2}-t_{1}\right)$ where, $\Sigma$ is the summation of, $\mathrm{i}_{1}$-disease incidence/severity at time $t_{1}, i_{2}$-disease incidence/ severity at time $t_{2}$. The AUDPCs were normalised into relative AUDPCs (RAUDPCs) by dividing them with the total area of the graph. RAUDPCs were plotted on the graph and subjected to analysis of variance (ANOVA) with GenStat software (GenStat, 2005) and means were separated using the least significant difference 
(LSD) at 5\% level of significance where significant differences were found from the ANOVA.

Evaluating sweetpotato cultivar reaction to virus infection following graft inoculation. A total of 20 healthy looking sweetpotato cultivars were potted and raised in a screen house using a completely randomised design (CRD) replicated five times. A leaf from cultivar Tanzania with a combination of SPFMV and SPCSV (which cause SPVD) was graft inoculated to each of the cultivars. The graft inoculated plants were diagnosed using serology to confirm infection by SPCSV and SPFMV. Disease severity was also scored every month for five months using a scale of 1-5. Based on the monthly severity average score per replication, the AUDPCs and RAUDPCs were calculated as described above. The RAUDPCs were subjected to ANOVA with GenStat software (GenStat, 2005) and means were separated using LSD at 5\% level of significance where significant differences were found from the ANOVA.

Yield and quality attributes. Sweetpotato cultivars were planted in the field in a RCBD with two replicates. Each block had 22 plots of $15 \mathrm{~m} \mathrm{X}$ $3 \mathrm{~m}$. Tuber yield, tuber number and vine fresh mass per plot were recorded at six months after planting. The tuber number per plot and above ground fresh weight per plot were regressed to yield per plot for the cultivars. The root shape, skin colour, flesh colour, level of root flesh oxidation and growth habit for all cultivars were recorded following the CIP/IBPGR descriptors for sweetpotato as described by Huaman (1991). The quality attributes which include $\beta$-carotene content (Reddy and Sistrunk, 1981), protein content (Kjeldahl method), dry matter content (Kjeldahl method), sugar content (Hodge and Hofreiter, 1972), fiber content (Hammett et al., 1966) and starch content (Pharr and Sox, 1982) were measured for all cultivars. The correlations among the six quality traits (dry matter, starch, sugar, protein, $\beta$-carotene and fiber content) were calculated.

Flowering, crossing and seed set ability. From the 22 sweetpotato cultivars, 13 were further selected for subsequent crosses based on their contrasting traits with respect to yield, SPVD resistance and quality attributes among others. The 13 chosen parents were used in the North Carolina 2 crossing to evaluate their flowering, crossing and seed set ability following the CIP/ IBPGR descriptors for sweetpotato as described by Huaman (1991). The agronomic and quality attributes of the 6 males (Munyeera, New Kawogo, Buliribwamese, Kisakyamaria, Tanzania and Bwanjule) and 7 females (Polyster, Tar, Beauregard, Silk, Sudan, Enjumula and Sowola) crossed are given in Table 1 . The crossing ability was noted as crosses were made in the field by noting the number of seeds produced in each family in attempt to achieve a total number of 50 seeds per family.

The possibility of self-fertilisation was tested by selfing five cultivars Munyeera, Sowola, Enjumula, Silk and Bwanjule. The conducive time of the day for successful fertilisation was also noted. When seed capsules were dry, they were collected and shelled to release seeds. The number of seeds obtained from each capsule was noted. The seed dormancy imposed by the hard seed coat was broken in two ways (i) by puncturing once the seed with a needle and (ii) by scarifying them with concentrated (98\%) sulphuric acid.

\section{Segregation level in the $F_{1}$ progenies of full sib} families. A total of 20 morphological markers were recorded according to CIP/IBPGR descriptors as described by Huaman (1991) on the parental cultivars and their $F_{1}$ progenies from the family produced by crossing the paternal cv. Munyeera and the maternal cv. Beauregard. The morphological traits were coded into binary data. To supplement these morphological markers, four RAPD primers were used to assess the level of segregation in this family as described by Connolly et al. (1994). The primers names and sequences used are B-08 5'-GTC CAC ACG G-3', RAPD-2 5'-GTTTCG CTC C-3', RAPD-15'-GGT GCG GGAA-3' and B185'-CCACAG CAG T-3'.

Genotypes were scored for the presence (1) or absence (0) of each polymorphic fragment. The binary data was used to calculate the distance matrices and a dendrogram was produced using the Treecon software and the neighbor joining strategy. All the $F_{1}$ full sib-families produced 


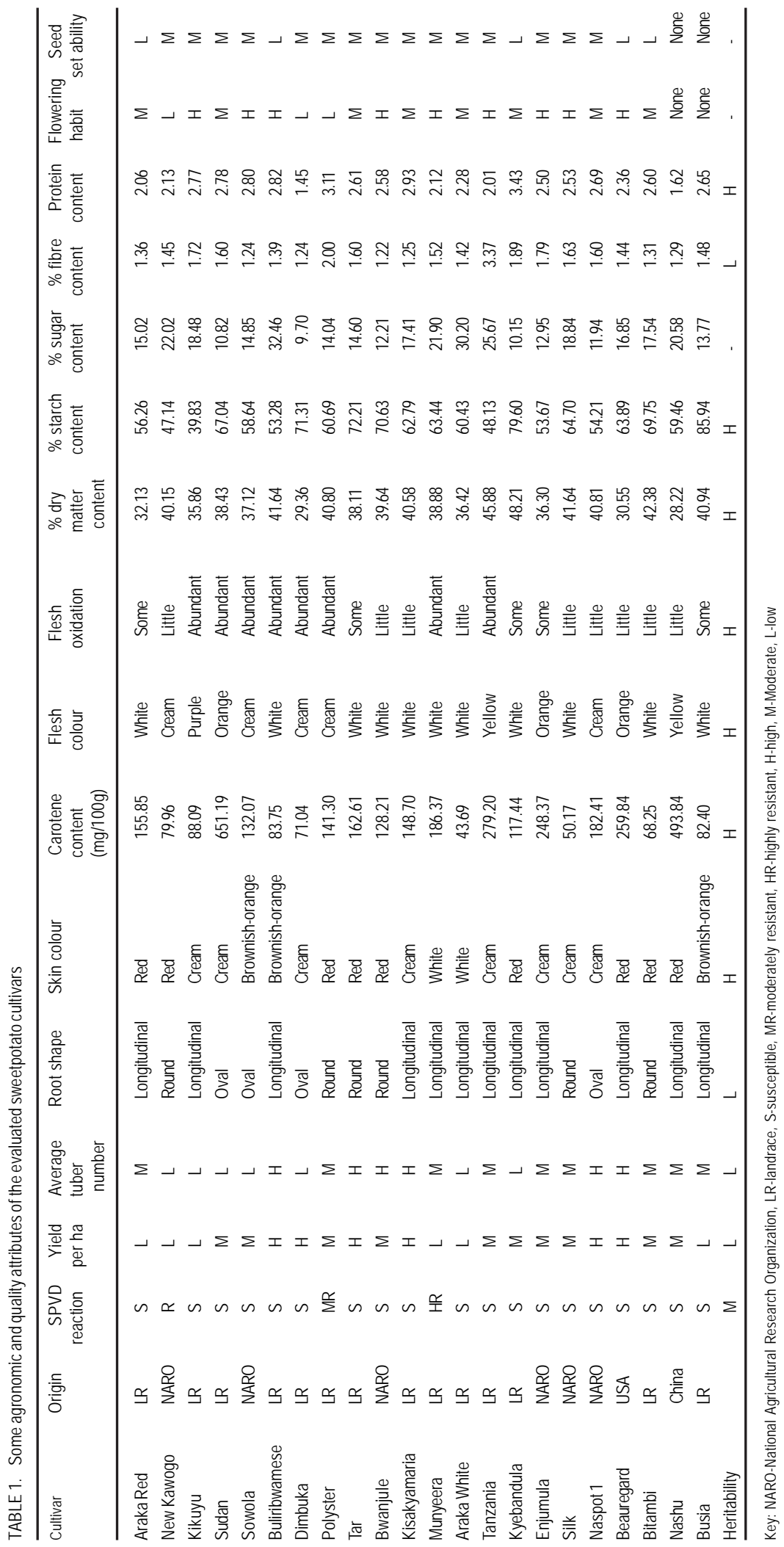


following a North Carolina 2 mating design, were planted in the field and the segregation was observed for traits of economic importance such as skin colour, flesh colour, SPVD resistance, tuber number and tuber yield.

\section{RESULTS AND DISCUSSION}

Phenotypic characterisation. From the phenotypic marker data that were coded into binary, a dendrogram (Fig. 1) was produced using neighbour joining algorithm with the Treecon software. The cultivars clustered separately from each other in distinct groups.

The two cultivars (Araka Red and Araka White) that are thought to be different by a possible mutation of the skin colour, displayed the highest bootstrap value of 100. This may reflect the reliability of the method and classification algorithm used. Most fusion points were associated with lower bootstrap values. Probably indicating the limitations of phenotypic markers used since only 57 markers were scored. The cultivar Kikuyu was in general very distinct from the rest of the accessions. It actually had some unique features like tuber flesh colour that is purple.

Cultivar reaction to natural infection. Under natural field infection, SPVD symptoms which include, leaf narrowing, distortion, chlorosis, mosaic, vein clearing and overall plant stunting were observed on all cultivars except for Munyeera, New Kawogo and Polyster. Significant differences $(\mathrm{P}<0.05)$ were observed on relative AUDPCs for the incidence and severity of SPVD in the field. Cv. Munyeera had the least relative AUDPC followed by New Kawogo and Polyster (Table 2). Similarly, these cultivars were grouped as highly resistant (Munyeera), resistant (New Kawogo) and moderately resistant (Polyster). The rest of the cultivars ranged from moderately susceptible to susceptible.

In the field, a few cultivars out of the 20 tested were infected with SPVD at three months after planting (MAP). However, during the course of five MAP, all test cultivars succumbed and showed typical SPVD symptoms with the

\section{Distance 0.1}

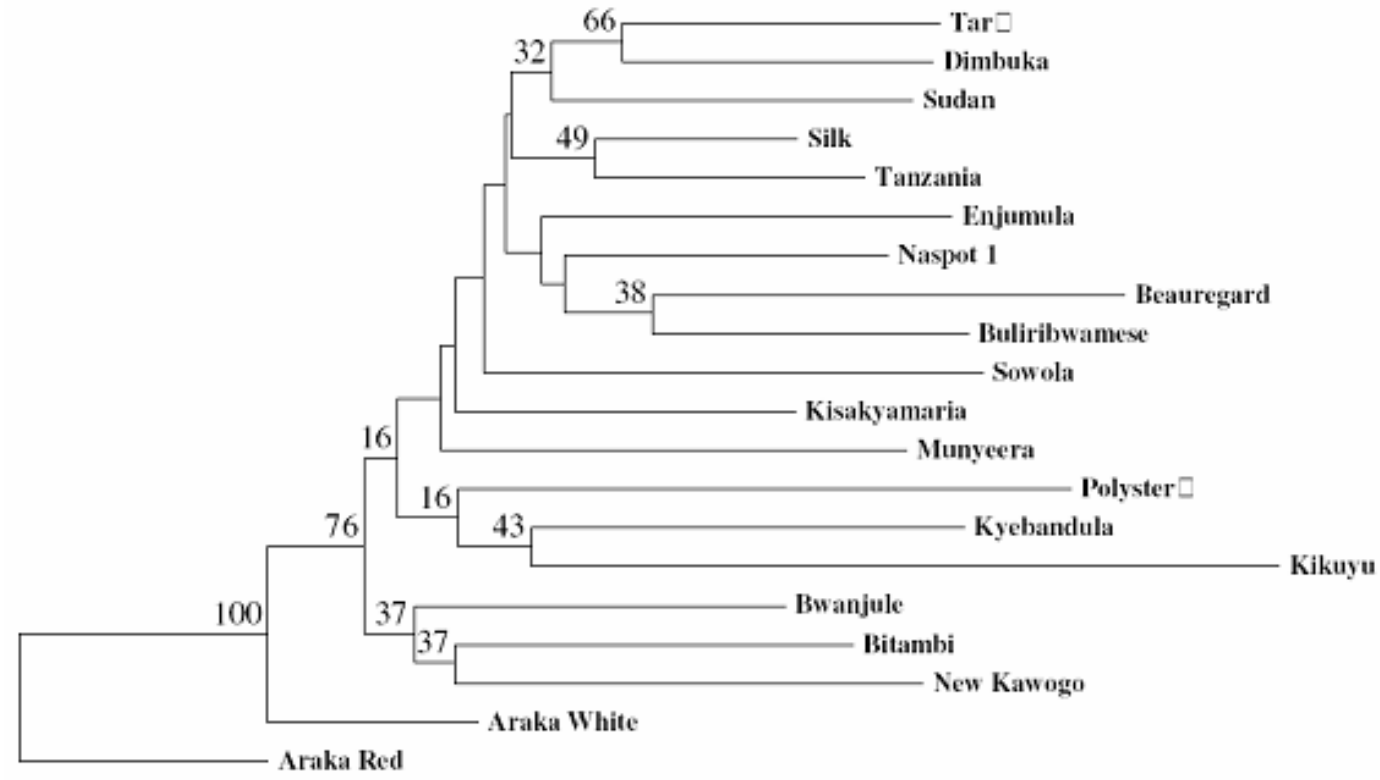

Figure 1. Dendrogram showing clustering of sweetpotato cultivars using Neighbor joining algorithm. The values at the branch nodes show bootstrap values out of 100 sampling times. 
TABLE 2. Progress of SPVD based on severity in graft-inoculated cultivars and incidence following natural infection in the field following natural infection

\begin{tabular}{|c|c|c|}
\hline Cultivar & $\begin{array}{l}\text { Progress of SPVD based on } \\
\text { incidence RAUDPC in the field* }\end{array}$ & $\begin{array}{l}\text { Progress of SPVD based on severity } \\
\text { RAUDPC in graft- inoculated cultivars* }\end{array}$ \\
\hline Munyeera & $0.200^{\mathrm{a}}$ & $0.233^{a}$ \\
\hline New Kawogo & $0.369^{b c}$ & $0.379^{b}$ \\
\hline Polyster & $0.503^{c d}$ & $0.502^{c}$ \\
\hline Kisakyamaria & $0.559^{\text {de }}$ & $0.631^{d}$ \\
\hline Tanzania & $0.572^{\text {def }}$ & $0.615^{\mathrm{cd}}$ \\
\hline Araka White & $0.584^{\text {def }}$ & $0.665^{d}$ \\
\hline Sowola & $0.603^{\text {def }}$ & $0.619^{\text {cd }}$ \\
\hline NASPOT 1 & $0.656^{\mathrm{efg}}$ & $0.671^{\text {de }}$ \\
\hline Beauregard & $0.675^{\text {efgh }}$ & $0.692^{\text {de }}$ \\
\hline Bwanjule & $0.678^{\text {efgh }}$ & $0.702^{\text {def }}$ \\
\hline Kyebandula & $0.719^{\text {fghi }}$ & $0.729^{\text {defg }}$ \\
\hline Enjumula & $0.719^{\text {fghi }}$ & $0.788^{\text {efgh }}$ \\
\hline Nashu & $0.769^{g h i j}$ & $0.713^{\text {defg }}$ \\
\hline Bitambi & $0.775^{\text {ghij }}$ & $0.817^{\mathrm{fghi}}$ \\
\hline Sudan & $0.825^{\mathrm{hij}}$ & $0.825^{\mathrm{ghi}}$ \\
\hline Tar & $0.856^{i j}$ & $0.854^{\mathrm{hi}}$ \\
\hline Silk & $0.862^{i j}$ & $0.883^{\mathrm{hi}}$ \\
\hline Zapallo & $0.869^{i j}$ & $0.871^{\mathrm{hi}}$ \\
\hline Kikuyu & $0.912^{j}$ & $0.917^{i}$ \\
\hline Araka Red & $0.912^{j}$ & $0.917^{i}$ \\
\hline $5 \%$ LSD & 0.15 & 0.12 \\
\hline
\end{tabular}

*Means followed by the same letter are not significantly different at $5 \%$ level of significance

exception of Munyeera, New Kawogo and Polyster (Table 2), thus confirming resistance in these cultivars as was noted in the graft inoculation study. The delay of the tested cultivars to get the disease in the field may not be attributable to vector resistance per se but was rather an escape because some of these cultivars did not posses any phenotypic attributes (e.g. pigments or hairs) which could repel the vectors.

Cultivar reaction following graft inoculation. Severe symptoms for SPVD developed on most of the cultivars that were graft inoculated. Symptoms observed include, leaf narrowing, distortion, chlorosis, mosaic, vein clearing and overall plant stunting on all cultivars except for Munyeera, New Kawogo and Polyster which showed relatively mild symptoms. A significant difference $(\mathrm{P}<0.05)$ was found on relative AUDPCs. Three cultivars were resistant to SPVD, with Munyeera having the least relative AUDPC followed by New Kawogo and Polyster (Table 2). This shows some levels of genetically controlled resistance in these three cultivars. These cultivars were grouped as highly resistant (Munyeera), resistant (New Kawogo) and moderately resistant (Polyster).

Disease escape would probably complicate the process of developing resistant cultivars rendering graft inoculation, that was also used in this study to confirm the resistance observed in the field, an effective screening method of assessing the reaction of cultivars to virus infection. Based on the combined field evaluation and graft inoculation studies, the landrace Munyeera proved to be more resistant to SPVD than the released variety, New Kawogo reported by Mwanga et al. (2002) from the previous searches for resistance sources. The observation that Munyeera is more resistant than New Kawogo is also supported by Mwanga et al. (2002) who reported that the SPVD severity scores of New Kawogo ranged from 2.3 to 4.3, consistent 
with observations of this study. This shows that Munyeera could be used as a new source of modest resistance in preference to both New Kawogo and Polyster unless the breeding program prefers some other traits not found in Munyeera. Cvs. Tanzania, NASPOT 1 and Sowola were previously reported to be resistant but based on severity and incidence data (Table 2) from this study, they proved to be susceptible. Further more, this study evaluated resistance to SPVD following graft inoculation unlike many previous reports which focused on resistance following natural virus infection.

Yield and quality attributes. The cultivars possessed different plant type, tuber number, tuber shape, tuber weight, tuber flesh colour, tuber skin colour, dry matter content, betacarotene content, starch content, sugar content, level of flesh oxidation and fiber content (Table 1). The cultivars were grouped according to their yield into three classes; high yielding (18 - $30 \mathrm{t}$ $\mathrm{ha}^{-1}$ ), moderately yielding (11-17 $\mathrm{tha}^{-1}$ ) and low yielding (less than $11 \mathrm{t} \mathrm{ha}^{-1}$ ) as according to the National Agricultural Research Organization (NARO) sweetpotato breeding program (Mwanga et al., 2002). There was a positive correlation $(\mathrm{r}=0.58 ; \mathrm{P}<0.05)$ between yield and tuber number. However, the regression line accounted for $53 \%$ of the total variance.

Cultivars like Beauregard, Tanzania, Buliribwamese, Kisakyamaria and Tar are high yielding almost at par with NASPOT 1, an improved variety. The root yield depends on the number of storage roots per plant as was also noted by Wilson et al. (1989). Thus, tuber number can then be used to predict the yielding potential of given cultivars. However, as the tuber number increases the dry matter content may be compromised as the plant will not be able to supply all the tubers with enough photoassimilates needed for tuber bulking. In most cases, few large tubers are preferred to many small ones. This tuber yield is also related to earliness in maturity, a preferred attribute in areas where sweetpotato is needed as a commercial crop and/ or to escape late season drought.

The highest $\beta$-carotene content was recorded in orange fleshed cultivars (Table 1) suggesting that the intensity of orange colouration is related to the amount of $\beta$-carotene present. Takahata et al. (1993) also found a strong positive correlation between $\beta$-carotene content and colour values in sweetpotato cultivars. This shows that the colour value could be used in rapidly estimating the $\beta$ carotene content in breeding programs. Some cultivars had high $\beta$-carotene content that was comparable to levels found in carrots, a known $\beta$-carotene rich food crop (Takahata et al., 1993). This reflects the potential of orange fleshed sweetpotato to substitute other $\beta$-carotene rich food crops like carrots. Thus, orange fleshed sweetpotato can be a cheaper complementary source of vitamin A. Furthermore, orange fleshed cultivars can be easily adopted by the poor agrobased families in Uganda who are already widely growing and depending on sweetpotato for food security and income. If orange fleshed sweetpotato is used in breeding for $\beta$-carotene content, the improvement is expected to be rapid since the heritability for $\beta$-carotene was reported to be high (Wilson et al., 1989).

All of the cultivars (Table 1) have shown to satisfy the consumers' preference for dry matter content which was pegged between 28-35\% (Rees et al., 2003). Except for the findings of this report, orange fleshed varieties have been reported elsewhere for example by (Rees et al., 2003) to have relatively low dry matter content (less than $18 \%)$. Local landraces can make a significant contribution either as varieties per se or progenitors in breeding programmes, for the farmer preferred traits. Storage roots with high dry matter and high starch content are more suitable for secondary processed products such as starch and flour. Further more, Rees et al. (2003) noted that high dry matter tubers dry fast when processed and when cooked they remain firm and are said to be better than the soft and watery ones in terms of acceptability by consumers.

The percentage sugar content was relatively low across cultivars and this is desirable. Sugar content was negatively correlated $(r=-0.47, \mathrm{P}<$ 0.05 ) with starch content. The negative correlation increases as starch is converted to sugars by enzymes in the roots. Sugar to starch ratio may affect perishability than sweetness of the cooked tubers. Rees et al. (2003) reported that farmers root sweetness is subjective and is explained as a root taste that is neither very sweet nor very 
flat. Root sweetness refers to good taste rather than sugar content per se. The fiber content was also low in most genotypes except in cultivars Tanzania, Busia and Munyeera. Roots with low fiber content are desired by farmers and are considered sweet (good taste).

Protein content was positively correlated $(\mathrm{r}=$ $0.64 ; \mathrm{P}<0.05$ ) to dry matter content. Increase in dry matter content may require a corresponding increase in the amount of enzymes involved in the metabolism thus explaining a corresponding increase in the amount of proteins as dry matter increases.

In this study, white flesh-coloured cultivars have been identified (Table 1). White fleshed varieties are preferred because they produce good chips and good quality flour when processed (Rees et al., 2003). Rees et al. (2003) noted that farmers associate white flesh colour with high starch and dry matter content, whereas orange fleshed ones are associated with low dry matter content. Because of this reason, Rees et al. (2003) noted that consumers ranked white fleshed cultivars to be more preferred and important than orange fleshed cultivars indicating that many people are not aware on the importance of orange fleshed cultivars. This becomes a paradox in promoting orange fleshed varieties. Low oxidation maintains product quality and attractive appearance. Cultivars with little oxidation have been identified in this study (Table 1 ), holding much promise in improving sweetpotato for this trait.

Skin colour was also found to be more variable, raising potential to breed and select cultivars with skin colour preferred by farmers. Rees et al. (2003) reported that skin colour had a strong implication on preference and was highly subjective depending on individuals and market place. Rees et al. (2003) further noted that farmers associated skin colour with other traits like dry matter content and fiber content. In some cases, the skin colour is not considered, as farmers prefer yield, resistance to diseases and pest, dry matter or any other traits.

Root shape, which was variable, can also have influence in the market and depends on individuals. Smooth shapes are preferred to cracked, rough and wrinkled ones because of the easy in processing (washing and peeling) (Rees et al., 2003). Only cv. Sudan showed many cracks; the majority had few cracks to none. Most cultivars have shown to possess semi-erect growth habit with a few spreading and climbing ones. Farmers may like few branches in intercropping, whereas the spreading ones are needed in combating weeds. More so, spreading ones may produce many branches, thus proving more planting materials. However, they may produce thin poor planting materials and farmers may dislike them. Since vine length and stem thickness are highly heritable and maternally inherited (Wilson et al., 1989), its improvement is easy but should be done in compliance to the farmer preference.

Flowering, crossing and seed set ability. The flowering abilities of the evaluated sweetpotato cultivars ranged from high to low (Table 1). Cvs. Munyeera, Buliribwamese, Tanzania, Bwanjule, Beauregard, Silk, Enjumula, and Sowola had high flowering abilities. Cvs. Sudan, Kisakyamaria and Tar had moderate flowering abilities, whereas cvs. New Kawogo and Polyster had low flowering abilities (Table 1). The seed set abilities of the above cultivars were found to be moderate (Table 1). Many sweetpotato cultivars including Beauregard, Tanzania, Munyeera, Buliribwamese, Bwanjule, Enjumula, New Kawogo, and Polyster crossed easily despite the fact that some cultivars like New Kawogo and Polyster had low flowering abilities. However, some cultivars such as Silk and Sowola as female parents were difficult to cross with specific male cultivars as was evidenced by both high levels of flower abortion and reduced number of seeds obtained in an attempt to raise 50 seeds. Cultivar Silk could not cross to Tanzania, whereas Munyeera and New Kawogo could not cross to each other even in reciprocal crossing. The five self-pollinated cultivars (except for Enjumula) failed to produce seed capsule (seeds), rather the fertilised flower stalk supporting the embryo remained intact for 1-2 days before it withered. When 50 flowers of Enjumula were self-pollinated, only 3 fertilised successfully to produce seeds. The hand pollinated flowers produced up to 2 and rarely 3 seeds per capsule as opposed to insect pollinated ones which produced up to 3 and sometimes 4 seeds per capsule. Generally, flowers pollinated 
in the early hours of the day (before 0900 hours) of the day had high levels of success in fertilisation. Needle punctured seeds produced healthy-looking seedlings compared to the acid scarified ones during the first week of seedling growth.

Flowering ability is an essential aspect in sweetpotato breeding since it determines the potential of improving certain cultivars through breeding. Cultivars like Busia and Nashu which did not flower present greater challenges in accessing their genes for sweetpotato improvement through convectional breeding. Another challenge occurs when cultivars can flower but failing to cross with specific cultivars as was observed with New Kawogo, Munyeera, Silk and Sowola. This means that accessing their genes is more difficult as it requires indirect crossing.

Compared to non-flowering cultivars, the low flowering ability observed in some sweetpotato genotypes can be compensated by increasing the replication number of those cultivars in the crossing block and optimising the environment during crossing to ensure successful pollination of those few flowers available. Fortunately, cultivars which carry desirable alleles also have moderate to high flowering and seed set ability suggesting that they can be used in cross pollination without any need for flowering synchronisation through staggering planting dates in the crossing block.

Despite the high flowering ability of some cultivars, their seed set abilities were moderate, highlighting some inefficiency in fertilisation successes. This shows that with such cultivars more crossing efforts may be needed to raise a certain number of seeds. Cross incompatibility can lead to a complete failure in seed set, hindering exploitation of some gene combinations during breeding. Self and cross incompatibilities have remained major challenges in sweetpotato breeding and genetic mapping since they hinder production of segregating populations from specific crosses. Insect pollinated flowers, produced 3 and at most 4 seeds from each seed capsule, whereas hand pollination yields 1 or at most 2 seeds per seed capsule showing the inefficiency of hand pollination compared to insect pollination. Possibly during insect pollination, the insects keep on bringing pollen grains, thus maximising the chance of the viable pollen landing on the stigma. Despite the high seed setting ability which was observed in almost all of the genotypes under open pollination some greatly reduced seed set abilities were observed during controlled (hand) pollination between specific cultivars especially crosses that involved cultivars Silk and Sowola. This could reflect the cross incompatibilities previously reported in this hexaploid crop, presenting a great challenge in making specific crosses during sweetpotato breeding.

Selfing in sweetpotato was generally not possible as was observed with cultivars Bwanjule, Munyeera and Silk. However, few seeds obtained with Enjumula (three seeds out of 50 flowers self pollinated) cannot provide concrete evidence that Enjumula can self fertilise to produce viable seeds. This could suggest that after tying the flowers in the field, chewing insects (such as beetles frequently observed hovering around the flowers) can bite and chew these flowers, exposing them once again to wind and insect pollination resulting in cross pollination that might have been confused to be selfing.

Pollination success was high in the early morning hours, however, from 0900 hours to 1000 hours, pollination was reduced, beyond 1000 hours the pollination was rarely successful. The time of cross pollinating is critical especially when the fertilisation success is to be maximised. Seed puncturing with a needle is better as it produces seedlings with good health during the first week of seedling emergence. However, seed puncturing with a needle can be laborious when large numbers of seeds are to be handled. This leaves acid scarification a better option in handling large numbers of seeds but there is a need to rigorously rinse the seeds to remove excess acids which may influence the initial seedling health.

Segregation level in the $F_{1}$ progenies and their breeding value. From four decamers random primers reported to generate a lot of polymorphisms by Connolly et al. (1994), 27 fragments were amplified in a family produced by crossing the parental cultivar Munyeera and maternal parent Beauregard, of which 15 were 
polymorphic. The data from 20 discriminating morphological markers recorded from this family were coded into binary and supplemented with RAPD data to produce a dendrogram. Most of the $F_{1}$ progenies did not resemble either of the parents but were rather intermediates except MXB-5 which clustered with Munyeera and MXB-9 which clustered with Beauregard.

An interesting feature is the level of segregation which was found to be high in the $F_{1}$ progenies based on the 20 morphological markers and four RAPD primers used. This probably indicated that segregation for many traits was occurring. Indeed, field evaluation of agronomic and quality traits from the $\mathrm{F}_{1}$ progenies produced from the selected 6 males and 7 females also revealed a lot of segregation (Table 3 ). This segregation was also noticed for SPVD resistance, tuber yield (Table 3), tuber number, tuber size and weight, tuber shape (Fig. 2).

A cross between resistant and susceptible parents produced both resistant and susceptible progenies. However, more resistant progenies were found in those families with Munyeera as the resistant parent. The family which produced and yield were from Munyeera and Beauregard. Crosses between susceptible parents produced only susceptible progenies (Table 3). This shows great potential to improve SPVD resistance using the SPVD resistant parents especially cultivar Munyeera. The $\mathrm{F}_{1}$ progenies also showed good yield in terms of tuber number (Table 3; Fig. 2). There was also a great potential to increase tuber size as well as tuber shape (Fig. 2), skin and flesh colour (Table 3). A tuber of up to $8.5 \mathrm{~kg}$ (Fig. 2G) was recorded. This shows a great breeding potential in these materials and in producing transgressive segregations useful to the farmers.

Cultivars evaluated proved to have one or more desirable traits like Beauregard and Tanzania which are both high yielding varieties with high $\beta$-carotene content (Table 1). However, some traits were reported to have different heritabilities (Wilson et al., 1989). With high heritability genetic gain is expected to be rapid. However, as in the cases where the genetic gain could be expected to be slow because of low heritabilities increasing number of replications in the trials and using better screening methods such as molecular

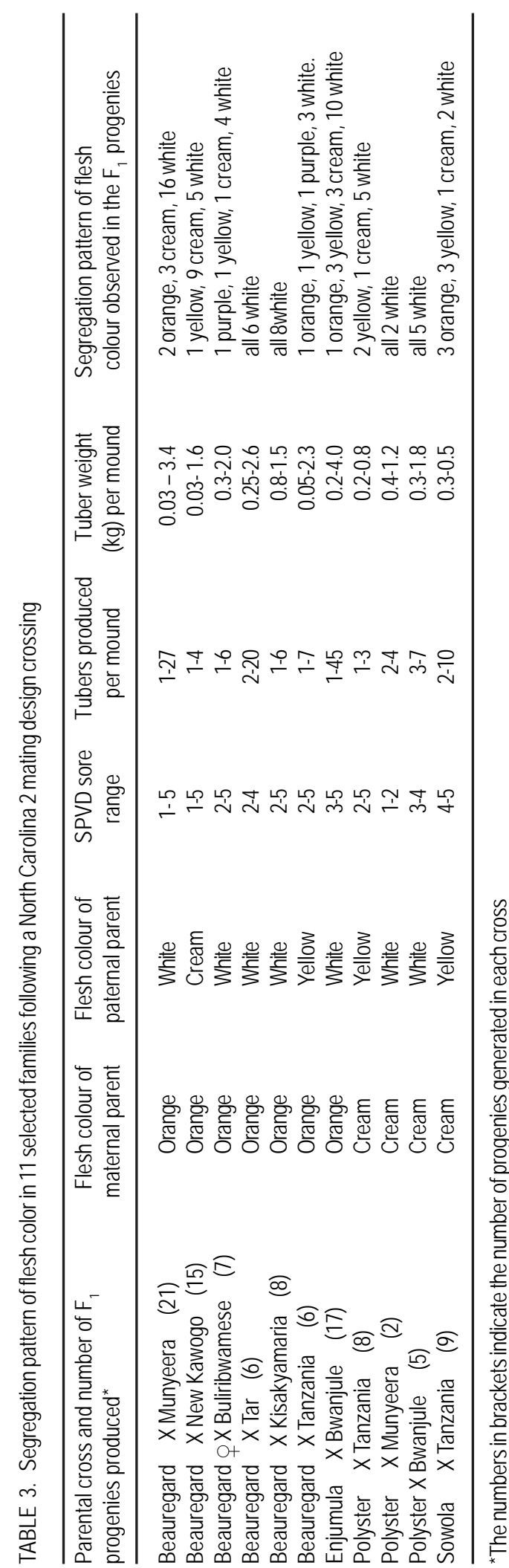




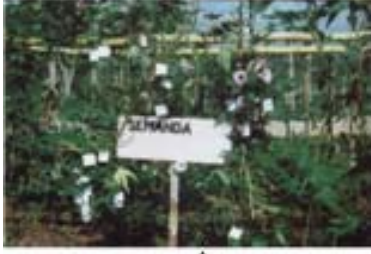

A

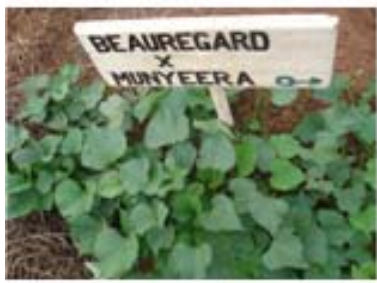

E

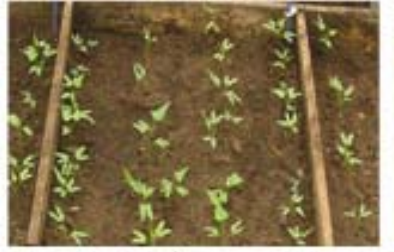

B

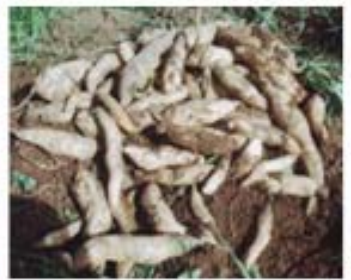

$\mathrm{F}$

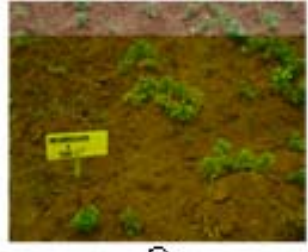

C

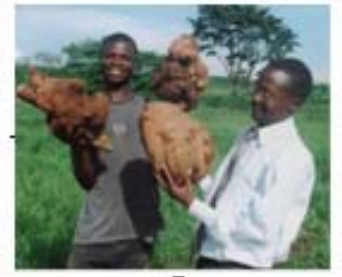

G

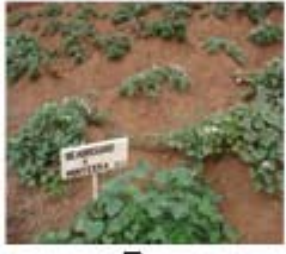

D

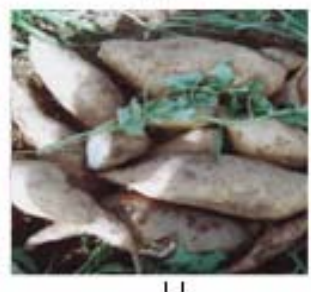

$\mathrm{H}$

Figure 2. The breeding process and performance of $F_{1}$ progenies. Cultivar Semanda in the crossing block $(A)$, sweetpotato $F_{1}$ progenies at seedling stage $(B), F_{1}$ progenies suffering from $S P V D(C), F_{1}$ progenies resistant to $S P V D(D$ and $E)$, traits for high yielding progenies such as tuber number of up to 45 tubers per mound $(F)$, very big tubers of up to $8.5 \mathrm{~kg}$ per tuber $(\mathrm{G})$, good tuber shape and size $(\mathrm{H})$.

markers will enhance the response to selection. Moreover, if the heritability is low, selection can be based on the breeding value of a seedling derived clone, as judged by the performance of its progeny (progeny testing) rather than on the parents.

A cross between an orange fleshed flesh coloured maternal parent Beauregard and a white flesh coloured paternal parent Munyeera produced orange, cream and white individuals. A cross between an orange fleshed coloured maternal parent Beauregard and a cream flesh coloured paternal parent New Kawogo produced yellow, cream and white progenies. A white fleshed individual crossed to a white fleshed or cream fleshed individual produced cream and white fleshed offsprings but not orange. Other segregation patterns for the flesh colour in different families are given in Table 3 . The purple skin colour could, however, emerge from any family irrespective of the skin colour of the parents (Table 3). No clear segregation patterns were produced in terms of tuber numbers and tuber yield. However, the parents with higher tuber number and yield also produced offsprings with high tuber number and yield.

The phenotypic classes produced for the flesh colour can not be consistently fitted into either the Mendelian monohybrid or di-hybrid ratios. This shows that these traits could be controlled by several genes with some epistatic interactions probably complementary gene actions. We can hypothesize that there are up to five separate genes each segregating in a Mendelian manner (segregating and assorting independently of each other). When they occur together in the common genetic back ground, the beta carotene pathway is complete and an orange flesh is formed, if one is missing probably the last one in the pathway, the colour becomes yellow, if the last two are missing the colour becomes cream, when any three are missing then the flesh colour becomes white. However, the intensity of these colours also differs across these progenies and we hypothesize that the flesh colour intensity is influenced by the gene dosage effects in this hexaploid crop. Where many alleles of the same gene probably involved in the final stage of the pathway are present, then the colour becomes intense and the opposite might be true. The purple flesh colour might be the modification of any one of those genes in the carotene production by some modifier genes in the genetic background. Given the rare nature of this purple colour, these modifier genes might be acting in a recessive fashion. 


\section{CONCLUSION}

The available sweetpotato germplasm in Uganda has a great potential to solve the SPVD problem, increase yield, improve nutritional quality and root appearance. Since most of the desirable traits were reported to be highly heritable, this shows that breeding could be rapid to meet the prevailing challenges. There is an urgent need for deliberate breeding efforts to manipulate and combine desirable traits in sweetpotato into a common genetic background. More so, identification of molecular markers could assist in breeding traits with low heritability like yield and SPVD resistance which can be more expensive and time consuming if based on progeny testing.

\section{ACKNOWLEDGEMENTS}

We thank the National Crops Resources Research Institute (NaCRRI), Namulonge, Uganda for the provision of some of the germplasm used in this study. We also appreciate the efforts of the laboratory and field technicians at Makerere University. Special thanks go Mr. Nelson Malli for assistance in experimental set up, monitoring and data collection. Ms. Agnes Alajo from NaCRRI, is greatly thanked for providing the technical support in sweetpotato breeding. This work was funded by Rockefeller Foundation through the RU-CG005 grant of the RUFORUM program and Sida/SAREC through the Sweetpotato project of the BIOEARN program.

\section{REFERENCES}

Campbell, C.L. and Madden, L.V. 1990. Introduction to plant disease epidemiology. John Wiley and Sons, New York.

CIP. 1999. Annual Report. International Potato Center, Lima, Peru.

Connolly, A.G., Godwin, I.D., Cooper, M. and Delacy, I.H. 1994. Interpretation of randomly amplified polymorphic DNA marker data for finger printing sweet potato (Ipomoea batatas L.) genotypes. Theoretical and Applied Genetics 88: 332-336.

FAO. 2004. FAO statistics http://apps.fao.org: Food and Agricultural Organization of the United Nations, Rome, Italy.
GenStat. 2005. GenStat for Windows Discovery, Second Edition. International Ltd. Lawes Agricultural Trust.

Gibson, R.W., Mpembe, J., Alicia, T., Carey, E.E., Mwanga, R.O.M., Seal, S.E. and Vetten, H.J. 1998. Symptoms, etiology and serological analysis of sweet potato virus diseases in Uganda. Plant Pathology 47: 95-102.

Grifffings, B. 1956. Concept of general and specific combining ability in relation to diallel crossing systems. Journal of Biological Science 9: 463-493.

Hahn, S.K. 1979. Effect of virus (SPVD) on growth and yield of sweetpotato. Experimental Agriculture 15: 253-256.

Hahn, S.K., Terry, E.R. and Leuschener, K. 1981. Resistance of sweetpotato to virus complex: No need for genetic analysis to SPVD resistance. Journal of American Society for Horticultural Science 16: 535-537.

Hammett, H.L., Hernandez, T.P. and Miller, J.C. 1966. Inheritance of fiber content in the sweet potato Ipomoea batatas (L) Lamb. Proceedings of the American Society of Horticultural Science 88: 486-490.

Hodge, J.E. and Hofreiter, B.T. 1972. In: Whistler, R.I. and Wolfrom, M.L. (eds). Methods in carbohydrate chemistry Volume 1. Academic Press, New York. p380.

Huaman, Z. (ed). 1991. Descriptors for sweetpotato. CIP/AVRDC/IBPGR, International Board for plant Genetic Resources, Rome, Italy.

Jones, A. 1986. Sweetpotato heritability estimates and their use in breeding. Horticultural Science 21: 14-17.

Mukasa, S.B., Rubaihayo, P.R. and Valkonen, J.T.P. 2003. Incidence of viruses and viruslike disease of sweetpotato in Uganda. Plant Disease 87: 329-335.

Mwanga, R.O.M., Kriegner, A., Cervantes-Flores, J.C., Zhang, D.P., Moyer, J.W. and Yencho, G.C. 2002. Resistance to Sweet potato chlorotic stunt virus and Sweet potato feathery mottle virus is mediated by two separate recessive genes in sweetpotato. American society for Horticultural Science 127: 798-806.

Nei, M. and Li, W.H. 1979. Mathematical model for studying genetic variation in terms of restriction endonucleases. Proceedings of the 
National Academy of Sciences of the USA Rees, D., Van Oirschot, Q. and Kapinga, R. 2003. 76: 5269-5273.

Pharr, D.M. and Sox, H.N. 1982. Changes in Sweetpotato Post-Harvest Assessment: Experiences from East Africa. Chatham, UK. carbohydrate and enzyme levels during the sink to source transition of leaves of Cucumis sativas L., a starchyose translocator. Plant science 35: 187-193.

Reddy, N.N. and Sistrunk, W.A. 1981. Effect of cultivar, size, storage and cooking method on carbohydrate and some nutrients of sweet potatoes, Ipomoea batatas. Food Science 45: 682-684. Takahata, Y., Noda, T. and Nagata, T. 1993. HPLC determination of $\beta$-carotene of sweetpotato cultivars and its relationship with colour values. Japanese Journal of Breeding 43: 421-427.

Wilson, J.E., Pole, F.S., Smit, N.E.J. and Taufatofua, P. 1989. Sweetpotato breeding. IRETA publications, Apia, Western Samoa.

Woolfe, J.A. (ed). 1992. Sweet Potato, an Untapped Food Resource. Cambridge University Press, New York. 